\title{
Maximal Preference Utilitarianism as an Educational Aspiration
}

\section{Andrew Stables}

School of Education, University of Roehampton, London, UK

Froebel College, Roehampton Lane, London SW15 5UP

andrew.stables@ roehampton.ac.uk; andrew.stables@icloud.com

Andrew Stables is Professor of Education and Philosophy and Deputy Director for Research in the School of Education at Roehampton University. He has worked previously at the Universities of Swansea and Bath and has held visiting positions at Ghent, Chaiyi and Oxford. 


\title{
Maximal Preference Utilitarianism as an Educational Aspiration
}

\author{
Abstract \\ This paper attempts to square libertarian principles with the reality of formal education \\ by asking how far we should and can allow people to do as they wish in educational \\ settings. The major focus is on children in schools, as the concept 'childhood' ipso facto \\ implies restrictions on doing as one wishes, and schools as institutions entail inevitable \\ constraints. Children by definition (however contested) tend to enjoy stronger protection \\ rights but weaker liberty rights than adults (XXX, 2011; Feinberg, 1980). A local \\ preferential calculus (after Bentham's felicific calculus) is developed as a guide for \\ teachers, suggesting wishes should be granted where feasible and at least welfare \\ neutral. In the case of teachers, employers set the parameters for the feasibility criterion \\ but should also ensure at least welfare-neutrality, while students in adult and higher \\ education should be responsible for the feasibility and welfare outcomes of their own \\ choices.
}

Keywords: utilitarianism, education, preference, philosophy

\section{Introduction}

The argument has four stages. The first defines and justifies maximal (as opposed to maximum) preference (as opposed to pleasure) utilitarianism, rejects flat universal utilitarian conceptions, and considers the problematic position of the child with respect to preference granting. The second considers the somewhat patchy treatment of utilitarianism in the philosophy of education literature. The third develops a specific local preferential calculus for school teachers, and the fourth considers the application of this to educational actors other than schoolchildren, specifically adult students and teachers. 


\section{Maximal Preference Utilitarianism}

Given that a school in which everyone did as they wished all the time would likely be chaotic, the first challenge is to justify the premise that preference utilitarianism has any value as an educational ideal. One important aspect of this relates to children and the degree to which they can and should be trusted to exercise preferences. This will be discussed below, but the argument as a whole is likely to attract sympathy only from those who are inclined to the view that important learning comes from exercising and taking the consequences of risks that one has taken on for oneself. Those who consider that children should have no significant rights to choose reject a basic premise underpinning this paper.

In relation to the justification of preference utilitarianism in education, it is important to note two implicit caveats in the title of the paper, and to make some other preliminary remarks by means of clarification of working concepts. The first concerns the term 'maximal' as opposed to 'maximum'. 'Maximal' implies a feasibility criterion not implied in 'maximum'. The espoused aim here, therefore, is not to allow all sorts of preference fulfilment all of the time and immediately, but rather to aim for schools and other educational institutions to be places where actors (teachers as well as students) can exercise their preferences as far as possible within institutional constraints, given that such constraints in part exist in order to protect (particularly in the case of children), without undue detriment to the preferences of others. 
The second caveat concerns the choice of 'preference'. The argument takes preference utility as a regulative ideal, along the lines of beauty or perfection: something constantly to be aimed for with the recognition that it can never be fully achieved. The question remains as to why such an ideal should be embraced even as an aspiration, however. Here there are what might crudely be termed more negative and positive justifications, broadly along the lines of Berlin's conceptions of negative and positive liberty: freedom from and freedom to (Berlin, 1958). The more negative argument might be taken from Hobbes, insofar as freedom is considered not as constructed through rights-granting so much as a natural condition part of which is necessarily conceded for mutual security (Hobbes, 2014). The more negative justification might also draw on Lyotard's argument that the postmodern condition is one of values fragmentation and 'incredulity towards metanarratives' (Lyotard, 1986: xvi). On this postmodern account, there are no better or more enduring grounds for education than the feasible granting of preferences, as no other candidate value (one might cite social justice, economic growth, or national identity) can command sufficient rational consensus. In both these cases, there are no stronger grounds for acting than in relation to preference, construed either as the untamed natural condition of humanity or the default position of a society lacking a cohesive value set. The positive justification rests in the value of motivation, given that granting preferences goes with the grain of personal motivation and thus encourages both 'deep' and lifelong learning (Marton and Säljö, 1976). In terms of a modern cliché, if we want people to do their best, we should let them pursue their (not merely our) dreams, acknowledging that in such pursuit these dreams will modify, informed by the consequences of actions in the world. While 'dreams' may take longer to develop than simple preferences, it is clear that those who have not yet entered, let alone left, formal 
adulthood are strongly motivated by personal aspirations This raises challenges in terms of how we consider childhood in relation to education, that will be addressed below.

It should also be noted that aspirations need not be either rational or fully articulated verbally, but may often be evident in action and attitude. At the most basic level, preferences are realized in the processes and development of practices. Just as understanding can be construed as 'know(ing) how to go on' (Wittgenstein, 1967: S154), preference can be construed as choosing how to go on; this happens inevitably and well before ratiocination. A child's preferences can to a large extent be interpreted from the direction of their play and responses, articulated and emotional, while a teacher's preferences are manifested as much in 'where they take the lesson' as in conscious utterance of opinions and biases. In effect, to allow feasible preferences in formal educational contexts is to allow situations to unfold in a manner that is not overly directed or constrained by the teacher, noting both the collective nature of classroom activity and the liberty rights of the teacher on the grounds of the argument here. Thus what is proposed is a sensitive negotiation, not a free-for-all.

It is therefore important to clarify the parameters of preference utilitarianism in this study, as the remarks above take us a long way from certain established forms of utilitarianism. Certain versions of particularly contemporary utilitarianism, including that of Peter Singer, demand a strong universality (Singer, 2011). On such a flat universal account, we should be as attentive to the preferences of a child on the other side of the world as to those of our own children. Notwithstanding the moral rigour of this position, the present argument accepts the inevitability of greater care and attention to those proximal than at great distance (XXX, 1998). This position is taken on 
pragmatic grounds, for three reasons. First, as members of educational communities (teachers, say, or students), our moral choices are inevitably principally about what we do with, for and about ourselves and a small group of others within our organizations. Secondly, a flat universalism runs the risk of undermining the utilitarian impulse entirely. As Bernard Williams has argued, the challenge of the utilitarian calculus on the world stage is so great as to be self-defeating, and has little to offer moral concerns such as that of personal integrity (Smart and Williams, 1983). At the level of universality, the boundary between utilitarianism and deontology almost disappears. It could be argued that where actions should be calculated on the basis of what is best for the world as a whole, the position is almost akin to acting on the basis of a categorical imperative. (It is perhaps this difficulty that allows Barrow, below, to argue that Plato's Republic is a utilitarian text.) Williams is thus right to critique utilitarianism in its most universalist forms, though not preference maximization per se that is not the focus of his argument. Individual preference satisfaction might, however, be offered as an alternative to Williams' personal integrity. In the context of formal education, if every action were carefully considered using a universal felicific calculus, then a) hardly anything could get done, as each calculation would be so difficult, b) individual actors' preferences would lose rather than gain salience, and therefore c) there would be no local advantage in adopting utilitarianism as an aspiration. A final consideration is the glib but nevertheless logical observation that if everyone looked to the interests of those around them, the world would be a better place than one in which there was endless wrangling over universal goods. This argument therefore proceeds on three assumptions. First, we are each driven by an instinct to survive and flourish. Although the strength of this may vary from person to person and time to time, it does not require legal permission, though it does require some legal parameters for the protection of self and others. The 
focus in this argument is on negative liberties (Berlin, 1958); it follows Hobbes in arguing for partial social restraint on freedoms that are enjoyed regardless of formal assent. Secondly, we learn through managing risk and consequence. The argument for this has been made fully elsewhere (XXX, 2016a.). However, it is grounded in a general pragmatism: what something turns out to be is the sum total of its effects. As Peirce put it (Peirce, 2011, first published 1878):

'Consider what effects, that might conceivably have practical bearings, we conceive the object of our conception to have. Then, our conception of these effects is the whole of our conception of the object.' (Retrieved from www.peirce.org/writings/p119.html 11 December 2015)

As actors balancing personal and social identities, both risk taking and feedback on our actions are integral to our development. Rom Harré has referred to this as Publication in his 'social reality matrix' whereby personal and social identities are formed through a cycle of Conventionalisation, Appropriation, Publication and Transformation (Harré, 1983). Thirdly, we wish in general for others to survive and flourish, but not to the same extent as ourselves (until we are overcome by extreme weakness, fear or old age) and those closest to us. Related to this, we have a better understanding of the preferences of those closest to us than those further away. Thus this argument rejects flat universalism as well as undermining any strong philosophical tendency to assert that children need to know what flourishing is before being allowed to attempt to flourish on their own terms. The will to flourish is inherent, an aspect of the survival instinct, and we are all motivated to learn, through experience, what 'flourishing' means for us. Philosophers can be part of, but not determine, this developing understanding.

A further piece of conceptual underlabouring is required with respect to the concept of childhood. The present argument can clearly not move forward on the basis that only 
adults know what is good for children, yet acknowledgment of childhood as a category in any form implies recognition of children's welfare and protection rights (Feinberg, 1980). Children play at being adults - as do adults - but are considerably less accountable for their actions in certain respects. Any educational planning must acknowledge the tension between motivation and protection in all its dealings, but particularly those with children.

This is not to argue that childhood is a fixed concept, but to acknowledge that its existence in any operational form implies a condition of less than full rational autonomy. There are several different influences on current conceptions of childhood: on one level, we are all children (so this conception is not even age-related); on another the young tend to be less competent than adult; on another, childhood's innocence and vulnerability bring with them valuable insights and propensities (Wordsworth's child 'as father of the man': 1802, retrieved from www.bartleby.com/145/ww194.html 11 December 2015). Nevertheless, all these views of the child imply beings who cannot be trusted with their own judgments to the extent that adults should be trusted as autonomous rational agents in modern post-Enlightenment societies, and who therefore require enhanced protection. On this ground, Feinberg stresses that liberty, or interest (we might say, preference) rights are principally adult rights, welfare rights are often common to adults and children, and children's rights are often protection rights. In short, children tend to be passive recipients of their rights, while adults are active espousers of theirs.

A problem with this view is that adults are not fully rational either. Indeed, either a 'fully rational' or 'fully irrational' being is inconceivable, unless we take all universal 
activity as rational, in which case children are as rational as adults. There is often hypocrisy in rationalist accounts insofar as assumptions of adult rationality may exclude large elements of the grown-up population, including foreigners, criminals, women and the mentally ill, let alone all non-human sentient beings. The idea that in a generally irrational universe, a small population of adult human beings 'like us' is rational is surely both indefensible and dangerous (See Stables, 2012, for a fuller development of this perspective). In any case, as all who have dealt with children are aware, children do have strong preferences. Indeed, while still legally children, young people in the teenage years are expected to make choices, such as what to do on leaving school, that will have lifelong consequences for them, including constraining to some degree their future actions as supposedly autonomous adults. Even very young children have strong preferences, albeit in contexts of extreme worldly inexperience. It is therefore surely part of the duty of educators to increase the capacity for, and scope of, preference fulfilment as children go through school.

\section{History of utilitarianism as an educational ideal}

Given its presence in political and ethical debate, it might be argued that utilitarianism receives surprisingly little explicit attention in philosophy of education. Utilitarian perspectives have, however, influenced educational debate from the outset. While many arguments for formal schooling were grounded in a felt need to discipline and otherwise constrain energetic youth (XXX, 2011, Ch. 3.1), Bentham's Chrestomathia advocated a school in which emulation and competition would replace corporal punishment, visual aids including art and wall diagrams would stimulate and support learning, and children would be grouped according to ability (Itzkin, 1978). West states that J.S.Mill argued for 'state supported education for all' (West, undated, retrieved from 
www.utilitarianism.co./utilitarianism.html 11 December 2015.) While others argued for mass education for compliance and discipline, either religious or military, the early Utilitarians sought it, at least in part, as a means towards self-fulfilment.

Paradoxically, the same impetus is evident in much of the deschooling literature, with its libertarian aspirations to escape the trammels of state-imposed content and teaching (e.g. Illich, 1995). Any argument questioning the level and extent of compulsion in schooling is underpinned by some desire to grant preferences (XXX, 2014, 2016b.; Papastephanou, 2014), though more universalist forms of utilitarianism may serve to quash individuality, as satirised in Dickens' portrayal of Gradgrind's school of 'facts' in Hard Times (Dickens, 2003, first published 1854).

One of the most extensive explicit defences of a utilitarian position in more recent literature is that of Barrow (1975). However, in arguing that Plato's Republic is a utilitarian text insofar as it offers a template for the wellbeing of all citizens, Barrow may be stretching definitions of utilitarianism beyond their usual limits. Plato does not appear to place high value on either pleasure or, more broadly, personal preference, but is rather dismissive of all experience based knowledge claims. Such a critique has been expressed by Brenda Cohen (Cohen, 1977). In a later, less specifically educational work, Barrow develops his argument for a form of rule-utilitarianism on the grounds that such rule following tends to produce happiness more often than not (Barrow, 2015). Such forms of utilitarianism are miles apart from preference utilitarianism: so far, indeed, that a strongly rationalist commentator might be inclined to reject the present argument as anti-philosophical. To a Platonist it is indeed anti-philosophical, as it grants greater value in many situations to individual opinion than to supposedly objective 
truth. However, such granting on the basis that it will promote stronger justification in the long term, as is argued below.

A happiness based utilitarian account (of a more conventional sort than Barrow's) is critiqued by Miles who has particular problem with the use of happiness as an aspiration for arts education (Miles, 2006). The paper to which Miles is responding, by James Tarrant, raised different criticisms of utilitarianism, and is in effect a critique of J. S. Mill (Tarrant, 2006). Miles's objection is along the lines that Tarrant's rejection of utilitarianism does not address the root of the problem. Regarding Miles, there is surely a case to be answered here, insofar as no one chooses to sit through Shakespeare's King Lear, say, in order for them to feel happier in the short term in any trivial sense. However, one may well have a preference to see King Lear, and preferences may be seen as instrumental in bringing extra happiness, in the broader sense of human flourishing, in the longer term. Watching King Lear can certainly enrich one's experience. It is to avoid simple preconceptions around happiness that the present argument focuses on preferences. (It may almost go without saying that utilitarianism has been subject to a number of crude caricatures: as an obsession with facts and calculation in Dickens' Hard Times, for example, the treatment of which in the novel is popularly characterised as a critique of utilitarianism ${ }^{\mathrm{i}}$.)

An argument for utilitarianism in relation to moral education by Hare has not attracted such criticism, perhaps in deference to Hare's status as a moral philosopher (Hare, 1981, 1992). Hare's rejection of intuitionism and emphasis on rational debate about moral language appear at first blush to exert a considerable strain on any argument for granting the untutored wishes of young children. However, it is important to bear in 
mind that Hare's objections are at least in part to those who simply assume universalist moral positions without argument, such as Rawls in his theory of justice (Rawls, 2005, first published 1971). Placing greater emphasis on justification of the grounds of belief rather than the mere fact of belief has the effect of bringing pleasure and preference satisfaction closer.

\footnotetext{
'Hare discusses, though in a different context (1981: 142-4), the pleasure machine imagined by J.J.C. Smart (Smart \& Williams 1983: 18) that maximizes the pleasures of a subject through generating a stream of illusory but enjoyable experiences. He sees it as an advantage of his variety of utilitarianism that, not being "formulated in terms of pleasure", it can give weight to whether "we prefer a life for ourselves plugged into the machines to one devoted to pursuits now considered normal and enjoyable".' (Price,
} 2014).

The present argument is that maximal feasible preference granting (bearing in mind the strong protection and welfare rights enjoyed by children) is more rather than less likely to lead young people to value justified rather than merely intuited preferences, in part simply because they will have been engaged in debate about what preferences should, or can feasibly, be granted, and in part because they will have learnt from the consequences of enacting preferences from a young age. There is, of course, a necessary circularity about this position as all forms of pragmatist and consequentialist ethics assume that questions of feasibility cannot ultimately be separated from those of rational desirability. If it ends up working, it is right to want it. (It is beyond the scope of this paper to discuss how far Hare acknowledges this.) Although context suggests this was not the main intended force of the comment, Hare acknowledges that some sort of educative process must precede all sense of moral certainty: 
'The moral convictions to which (intuitionist) thinkers want us to appeal are themselves the product of moral education' (Hare, 1992: 197), and

'What the children need to have learnt is how to think about such problems.' (Hare, 1992: 198)

It is the contention of the present argument that we learn 'how to think' with reference to our (broadly understood) empirical experience, and that such experience is enriched by our following our interests and inclinations as much as is feasible. Of course, there are necessary disciplines which, in conjunction with the outcomes of our own choices, also make us think but imposed discipline without scope for initiative tends to restrict rather than develop thinking.

This is not to assume that preferences are all of the same tendency. In Hare, 1981, for example, it is made clear that intensity of preference is a matter of concern, as are scope (including how any people are affected by the preference) and duration, and how we deal with preferences that are clearly illusory in some way. However, the fact that young children are likely to have naïve understandings of such concerns should not invalidate their finding out through the exercising of preferences given inevitable safeguards. The educational question is how best one learns 'to think about such problems'. Unless a strong mind-body dualism is adopted, which would seem counter to most forms of consequentialism, trying things out and learning from what happens must surely play its part in developing moral reasoning as well as moral convictions. In short, it is only by exposing preferences that we can rationally discuss their ethical 
implications, and such discussion can at least be informed by experience arising from preference granting.

In summary, the extent to which utilitarianism is accepted as educationally valuable is determined in part by construal of its parameters. Nevertheless, it is clear that utilitarian impulses of somewhat varied characters have played their parts in moulding the contours of contemporary educational debate. Specifically, the recognition that personal interest plays more strongly into than runs against universal good has been a useful counter-balance to the view that children simply have to be socialised and have all their preferences systematically beaten out of them: a counter-view to preference utilitarianism that not only underpins certain of the original arguments for compulsory education (XXX,2011, Ch.3.1) but also was sufficiently widely held to infuse the English literary tradition, as, for example, in the horrific account of Lowood School in Charlotte Brontë's Jane Eyre. (Brontë, 1992).

\section{The parameters of maximal preference utilitarianism for schoolchildren}

Taking all the above into account, it is appropriate to suggest a local and specific preferential calculus for the context of schools and other forms of educational encounter with children. This is termed preferential rather than felicific since we are following Bentham broadly but focusing on preference rather than happiness. It can be modified as a useful heuristic for course planning and tutoring in further, higher and adult education, as is discussed in the final section. 
A problem with the application of classical Utilitarianism to the teaching of children is that, on Bentham's calculation, the happiness/pleasure principle is likely to trump children's preference on the grounds that teachers know better than children what is likely to produce extended pleasure. Bentham's calculus has seven elements: Intensity (the intensity of the proposed pleasure); Duration (how long the effect will last); Certainty (the likelihood of the pleasure resulting from the action); Propinquity (the time taken until the effect); Fecundity (the likelihood of repetition); Purity (the absence of negative side-effects), and Extent (the number of people affected). While children will have experience sufficient for them to judge well on the Intensity criterion, their inexperience is likely to affect their judgment on all the other criteria. At first blush, therefore, it would seem that the best way to ensure children's experiences is to deny them preferences. However, with the exception of the world's Gradgrinds, it is generally accepted in liberal democratic societies that personal preference is central to the pursuit of happiness. The challenge is to create a formulation that considers issues of Duration, Certainty, Propinquity, Fecundity, Purity and Extent while still giving priority to children's albeit naïve preferences.

Based on each of the above considerations, therefore, the following is suggested. The question for educators is:

How do I link [my understanding of] this child's wishes to [my understanding of] the situation and the consequences of granting such wishes [bearing in mind Intention, Duration, Certainty, Propinquity, Fecundity, Purity and Extent], such that the child's wishes can be granted as far as is feasible without detriment to the child's welfare? 
(That is to say, such wish-granting must turn out to be at least welfare-neutral.)

The two key principles here are: 1 . the child's wishes; 2 . the calculation of their consequences and feasibility (for the school context itself severely limits the possible range of actions); 3. How to grant (1) as fully as possible in the light of (2).

Suppose, for example, that a child who requires less classroom time than most to achieve highly on the formal curriculum has the opportunity to visit a space centre for the day and much wants to. Current law forbids her being taken out of school. This calculus would likely permit it. The same might be true for a child who is failing to progress in certain classroom activities but has the opportunity to attend a sports training camp during term time to progress in an activity towards which he is strongly motivated. While the proposed model falls far short of an anarchistic free-for-all, it is, for all its hedges and safeguards, likely to prove vastly more permissive than current policies in England and similarly orientated polities.

In the everyday life of the classroom, it is pertinent to return to the earlier claim that preferences are realized in the processes and development of practices. Here, the implications of the proposed model will seem radical to those who oppose all forms of incorrectness, randomness and open-ended experiment. To allow feasible preference in many situations might be to allow children to work with a conceptualization that will ultimately be falsified. A minor but telling example comes from Kambouri's study of early childhood practices, in which children maintained that water is white (Kambouri, 2015). An important educational question concerns whether teachers should simply 
reject this assertion as wrong (as all expert opinion holds it to be) or encourage children to work with it to find out for themselves, and on their own terms, where the conceptualization is lacking. On the present account, the latter approach offers a possibility for deep learning that the former denies.

It should be stressed, however, that at no point has it been suggested that teaching is merely a matter of attempting to grant preference. It has been argued that preferences should be granted where feasible within the contexts of in loco parentis relationships and inevitable, but not unnecessarily extensive, institutional, organizational and curricular constraints. The scope for action in schools is necessarily circumscribed; the emphasis here is to allow for a much freedom of action as possible with minimal, rather than minimum, circumscription. Constraints entail protection and it has been acknowledged that children, by definition, are entitled to forms of protection, though it has not been the concern of this paper to explore these in detail. Education's processes can, will and should involve challenging habits and perceptions: learning and living more broadly always carry an element of disillusionment as past assumptions are challenged and disrupted. Adults tend to recognise more than children that chronic sweet eating rots one's teeth, and any calculus relating to children inevitably involves assessment of longer term pleasures and pains that inexperienced children may be less placed to make than experienced adults. To acknowledge this, however, is not to sanction constant overriding of children's immediate preferences on the grounds that they do not know what is best for them; ultimately, they must find this out for themselves as they live lives inevitably different, and differently contextualized, from ours. 
An interesting parallel to the children-and-sweets issue is that of adults-and-wine. Most adults recognize that anything more than limited alcohol intake is likely to be bad for them, but many continue with it. However, there is empirical evidence to show that controlled experimentation can procduce significant insights. The first example relates to what one pays for alcohol as opposed to the immediate health issue but is nevertheless relevant. There have been numerous blind tastings of wine that have surprised participants by revealing to them that they cannot, in fact, differentiate between cheap and expensive wines on the grounds of taste (Guardian, 2015). The second is both personal and widespread. The present author is aware of more than one individual who modified his or her drinking habits significantly as a result of reading about a study that described the health benefits to middle-aged moderate drinkers of giving up alcohol completely for a month (Daily Mail, 2015). Allowing choice and then being encouraged to reflect on it in a systematic way can have a much stronger educational effect than letting habits, good or bad, go unchecked. As far as is feasible and broadly safe, learning through experience has more powerful effects than merely listening and memorizing, and some vital experiences (such as watching King Lear, or some equivalently challenging play or film preferred by a child) can be had without any immediate danger to life and limb; in other cases, limited risk taking that involves small but real physical risk may be educationally valuable, as acknowledged by both Locke and Rousseau, for example (Locke, 1692; Rousseau and Bloom, 2001). If the aim of education is in part to produce responsible citizens, it is hard to see how this can be done without allowing children to take some responsibility and to learn from the consequences of so doing.

\section{Application beyond children}


This final section considers how far the local calculus above for the following two groups: adult students in voluntary (further or higher) education, and teachers at all system levels.

Students in further and higher education of legal adult age have voluntarily entered into a contract to undertake a course. Should this not conform to their wishes, they can leave. If there are issues of funding that render this problematic, these could be addressed, but it must be assumed in general that teachers/lecturers are largely granting the students' preferences, and the students, as adults, are free to request modifications to the course should this be felt not to be the case in certain respects. On these grounds, the responsibility of teachers towards adult students is significantly different from that towards children.

This is not to deny the common triadic framework between all teaching situations: that of teacher-student-subject. Higher education teachers, like those in schools, are inducting students into disciplinary practices. The difference lies with the older student having entered into the contract to undertake this work voluntarily. The terms of engagement should therefore be broadly analogous with those relating to entry into all forms of contract: the student should know roughly what type and level of service to expect and should have appropriate forms of complaint and redress available as appopriate. This contrasts with the child who cannot be presumed to know roughly what to expect as s/he is not, in legal terms anyway, regarded as an autonomous rational agent. This means that in further and higher education the terms of the contract are of utmost importance, as are the known consequences for significantly departing from it. The contract can determine, in broad but agreed terms, the level of student preference 
and choice that will operate. This is a very different situation from that applying to a formal school.

Teachers themselves should be considered with respect to this model also. To an extent, the relationship of teacher to employer is synonymous with that of child to schoolteacher: that is, the employer has responsibility for the wellbeing of the teacher but also inevitably constrains her actions to a considerable degree. However, having appointed a teacher on the understanding that he can exercise his professional judgment flexibly with respect to the children he teaches, due regard should also be paid to the teacher's own requests for professional and personal development. As with children, there are advantages to be gained from going with the grain of teachers' motivations by allowing their preferences (within the boundaries of their employment of teaching only) as far as is feasible without detriment to others.

\section{Concluding remarks}

I have argued that students' preferences, including those of very young children, should play their part in determining and modifying educational provision, allowing teaching, as far as is possible, to go with the grain of learner motivation. This has particular implications for schools (as opposed to institutions of further and higher institution) which are premised on the assumption that children do not know what is best for them, so have very restricted liberty rights, though they enjoy strong welfare and protection rights. A preferential calculus for use by teachers in schools is suggested, and there is discussion about how far such a calculus should be relevant to adult students, or indeed to teachers themselves. It is hoped that this may contribute to further discussion about the still relatively neglected issue of the degree to which educational aims should 
incorporate compulsion on the one hand and, on the other, attempt to respond to individual preferences. 


\section{References}

Barrow, Robin (1975) Utilitarianism and Education. London: Routledge and Kegan Paul.

Barrow, Robin (2015, first published 1991) Utilitarianism: a contemporary statement. London:

Routledge.

Berlin, Isiah (1958) Two Concepts of Liberty. In Isaiah Berlin (1969) Four Essays on Liberty.

Oxford: Oxford University Press.

Brontë, Charlotte (1992) Jane Eyre. Ware: Wordsworth.

Cohen, Brenda (1977) Review of Barrow: Utilitarianism and Education. Mind 86/341, 130-132.

Daily Mail,The (2015) http://www.dailymail.co.uk/news/article-3289187/Month-drinking-

slashes-risk-disease-Abstaining-heal-liver-lower-blood-pressure-cholesterol-levels.html

accessed 18 December 2015

Dewey, John (1915/1944) The School and Society. Chicago: University of Chicago Press.

Dewey, John (1897) My Pedagogic Creed First published in The School Journal, LIV(3), 7780.

Dewey, John (1916) Democracy and Education. Toronto: Macmillan.

Dewey, John (1925) Experience and Nature. La Salle, IL: Open Court.

Dickens, Chalres (2003, first published 1854) Hard Times. London: Penguin.

Feinberg, Joel (1980) The Child's Right to an Open Future. In W. Aiken and H. LaFollette (eds.). Whose Child? Totowa, NJ: Rowman \& Littlefield: 124-53.

Guardian, The (2015) http://www.theguardian.com/lifeandstyle/2013/jun/23/wine-tasting-junkscience-analysis accessed 18 December 2015

Hare, Richard Mervyn (1981) Moral Thinking: Its Levels, Method and Point (Oxford:

Clarendon Press), and (1992) Utilitarianism and Moral Education. Studies in Philosophy and Education 11/3, pp.197-205.

Harré, Rom (1983) Personal Being: a theory for individual psychology. Oxford: Blackwell. Hobbes, Thomas (2014) Leviathan. https://ebooks.adelaide.edu.au/h/hobbes/thomas/h681/ Accessed 11 December 2015.

Illich, Ivan (1995) Deschooling Society. (New York: Marion Boyers) 
Itzkin, Elissa (1978) Bentham's Chrestomathia: Utilitarian Legacy to English Education.

Journal of History of Ideas 39/2, 303-316.

Kambouri, Maria (2015) Investigating Early Years Teachers' Understanding and Response to Children's Preconceptions. European Early Childhood Education Research Journal 25/3,

DOI: $10.1080 / 1350293 X .2014 .970857$

Locke, John (1692) Some Thoughts Concerning Education.

http://legacy.fordham.edu/halsall/mod/1692locke-education.asp Accessed 11 December 2015.

Lyotard, Jean-François (1986) The Postmodern Condition. Manchester: Manchester University

Press, p.xvi.

Marton, Ferenc and Säljö, Roger (1976) On Qualitative Differences in Learning — 1: Outcome and Process. British Journal of Educational Psychology 46, 4-11.

Miles, T.G. (2006) Utilitarianism and Education: a reply to James Tarrant. Journal of

Philosophy of Education 26/2, 261-264.

Papastephanou, Marianna (ed.) (2014) Philosophical Perspectives on Compulsory Education.

Dordrecht: Springer.

Peirce, Charles Sanders (1878) How to Make Our Ideas Clear. Retrieved from

http://www.peirce.org/writings/p119.html, 13 October 2011. Originally published in Popular

Science Monthly 12, pp. 286-302.

Price, Anthony (2014) Richard Mervyn Hare. Stanford Encyclopedia of Philosophy.

http://plato.stanford.edu/entries/hare/ Accessed 11 December 2015

Rawls, John (2005, first published 1971) A Theory of Justice. Cambridge, MA: Harvard

University Press.

Rousseau, Jean-Jacques and Bloom, Alan (2001) Émile: or On Education. Harmondsworth:

Penguin.

Singer, Peter (2011) Practical Ethics. Cambridge: Cambridge University Press.

Smart, Jack and Williams, Bernard (1983) Utilitarianism: for and against. Cambridge:

Cambridge University Press. 
Tarrant, James (2006) Utilitarianism, Education and the Philosophy of Moral Insignificance.

Journal of Philosophy of Education 25/1, 59-67.

Taylor, Brian (1982) A Note in Response to Itzkin's "Bentham's Chrestomathia: Utilitarian Legacy to English Education". Journal of the History of Ideas

Vol. 43, No. 2 (1982), pp. 309-313

West, Henry (undated) Utilitarianism. Encyclopedia Britannica. Retrieved from www.utilitarianism.com/utilitarianism.html 11 November 2015.

Wittgenstein, Ludwig (1967) Philosophical Investigations. Oxford: Blackwell, S154

Wordsworth, William (1802) My Heart leaps Up When I Behold a Rainbow in the Sky. http://www.bartleby.com/145/ww194.html Accessed 11 December 2015.

XXX (1998) Proximity and Distance: moral education and mass communication, Journal Philosophy of Education 32/3, 399-407.

XXX (2009) Should the Debate About Compulsory Education Be Re-Opened? 2009 Philosophy of Education, Urbana, IL: Philosophy of Education Society, U.S., 153-165.

XXX (2011) Childhood and the Philosophy of Education: an anti-Aristotelian perspective. London: Continuum.

XXX (2012) Be(com)ing Human: Semiosis and the Myth of Reason. Rotterdam: Sense. XXX (2016a) The End(s) of Learning and the Role of Instruction: shaping the debate. In Witt, P. (ed.) Handbooks of Communication Science Vol. 16: Communication and Learning. Berlin: Mouton de Gruyter.

XXX (2016b - awaiting publisher confirmation) Schooling vis-à-vis Learning: the case for reducing compulsion. In Siljander, P. (ed.) What is School? The Old Concept and New Conceptions

XXX, Jones, Sonia and Morgan, Carol (1999) Educating for Significant Events: the application of Harré's social reality matrix across the lower secondary school curriculum, Journal of Curriculum Studies 31/4, 449-461. 


\section{Notes}

${ }^{i}$ See, for example, the quite misleading definition of Utilitarianism as a philosophy that takes no heed of individual interests in <www.charlesdickensinfo.com/novels/hard-times/> (accessed 18 November, 2015) 